\title{
Induction of somatic embryogenesis from immature zygotic embryos and young apical leaves in cork oak (Quercus suber L.)
}

\author{
Zineb Nejjar El Ansari - Brahim El Bouzdoudi - Tomader Errabii - Rabah Saidi Mohammed L'bachir El Kbiach
}

Received: 14 January 2021 / Revised: 24 March 2021 / Accepted: 24 March 2021

(C) Korean Society for Plant Biotechnology

\begin{abstract}
The present work aims to study the induction of somatic embryogenesis in cork oak (Quercus suber L.) from immature zygotic embryos and young apical leaves obtained from 2-month-old seedlings through acorn germination on sterilized peat. The immature zygotic embryos were grown for 1 month on the mineral solution of MS in the presence of $4.52 \mu \mathrm{M} 2,4-\mathrm{D}$ and $30 \mathrm{~g} / \mathrm{L}$ sucrose. They were then transferred to the same mineral solution with no added growth regulators. In the third subculture, yellow somatic embryos, characterized by two voluminous cotyledons, were differentiated from the radicle of the immature zygotic embryos. The induction of somatic embryogenesis in young leaves required a series of transfers on different culture media containing $30 \mathrm{~g} / \mathrm{L}$ sucrose and $100 \mathrm{mg} / \mathrm{L}$ myo-inositol. Secondary or recurrent somatic embryogenesis occurred within the immature somatic embryo radicles after 1 month of culture on growth regulator-free medium containing WPM macronutrients, MS micronutrients, and vitamins.
\end{abstract}

Keywords Cork oak, Quercus suber L., Immature zygotic embryos, Young apical leaves, Somatic embryogenesis

\section{Introduction}

Cork oak (Quercus suber L.) is a forest species playing

Z. Nejjar El Ansari · T. Errabii · M. L. El Kbiach

Biology Department, Faculty of Sciences, Abdelmalek Essaadi

University, Tetouan, Morocco

B. El Bouzdoudi $(\bowtie)$

Environmental Technologies, Biotechnology and Bio-resources

Valorisation Team (ETBBV), Department of Biology, Faculty of Science and Technology Al Hoceima, Abdelmalek Essaadi University, Tetouan, Morocco

e-mail: belbouzdoudi@uae.ac.ma

R. Saidi

Sciences of Matter and Life Department, Tetouan Higher Teacher Training College of Tetouan, Abdelmalek Essaâdi University,

Tetouan, Morocco a major role in many Mediterranean ecosystems. Besides, this tree produces cork of economic value for the champagne and wine stopper industry and many other manufactures, contributing to the rural development in its natural area. However, cork oak is a long life cycle tree with irregular fructification seasonality and difficulty of seed conservation. Furthermore, vegetative propagation of mature individuals is not viable by classic methods. Thus, all these difficulties have impeded the development of genetic improvement programs for this species (Gomez-Garay et al. 2014).

Somatic embryogenesis provides a valuable tool that allows a massive production of clones in a very short time and from a minimal amount of plant material (Bonga 1991). As well, this technique can resolve problems of yield and intraclonal variability (Merkle 1995). The success of somatic embryogenesis has been reported in a large number of forest species (Dunstan et al. 1995; Thorpe et al. 1991). Secondary or recurrent embryogenesis is a proliferative process by which new embryos are developed from preexisting somatic embryos (Hernández et al. 2003a; Pinto et al. 2002; Pinto et al. 2008; Puigderrajols et al. 1996). This step offers somatic embryogenesis its potential for clonal mass propagation.

Somatic embryogenesis in cork oak was successfully carried out from zygotic embryos (Bueno and Manzanera 1992; Bueno et al. 1992; El Maataoui and Espagnac 1989; Manzanera et al. 1993; Pintos et al. 2008; Toribio 1986; Toribio and Celestino 1989), internodes (El Maataoui and Espagnac 1987; El Maataoui et al. 1990; Feraud-Keller et al. 1989) and leaves (Fernandez-Guijarro et al. 1993; 1995; Hernandez et al. 2003a).

In this work, we investigated the possibility of obtaining somatic embryos from immature zygotic embryos, excised at different growth stages, and from young leaves of cork oak. We were also interested in the amplification of embryogenic lines by secondary embryogenesis. 


\section{Material and methods}

Plant material

Healthy acorns of cork oak (Quercus suber L.) from an elite $(+)$ tree were kindly provided by the AIN RAMI Seed Conservation Center (Chefchaouen, Rif Occidental, altitude $560 \mathrm{~m}$, latitude $35^{\circ} 08^{\prime} 09^{\prime \prime} \mathrm{N}$, longitude $05^{\circ} 16^{\prime} 39^{\prime \prime}$ $\mathrm{W}$, mean rainfall $1400 \mathrm{~mm}$ and subhumid bioclimate in fresh winter). Immature acorns were collected in September and were stored in the dark at $4^{\circ} \mathrm{C}$ for one week. Mature acorns were collected in November and were stored in canvas bags in the dark at $4^{\circ} \mathrm{C}$.

Somatic embryogenesis from immature embryos

\section{Sterilization of immature acorns}

The green immature acorns of $31 \mathrm{~mm}$, free of their in teguments, were superficially sterilized for 30 minutes in a filtered solution of $7 \%$ calcium hypochlorite $\left(\mathrm{Ca}(\mathrm{ClO})_{2}\right)$ containing a few drops of Tween 80 , followed by a $0.1 \%$ Mercuric chloride solution $\left(\mathrm{HgCl}_{2}\right)$ bath for 5 minutes. $\mathrm{HgCl}_{2}$ is then removed by three successive rinses of 5 minutes each, in sterile distilled water.

\section{Sterilization of embryonic axes}

Embryonic axes of the cotyledons were aseptically isolated and sterilized for 10 min with a 5\% (w/v) filtered solution of calcium hypochlorite containing a few drops of Tween 80 , followed by three rinses with sterile distilled water of about 5,5 and $10 \mathrm{~min}$.

\section{Culture media}

The nutrient medium used as a reference is composed of Sommer macronutrients (Sommer 1975), Murashige and Skoog (MS) micronutrients and vitamins (Murashige and Skoog 1962), $100 \mathrm{mg} / \mathrm{L}$ myo-inositol, $500 \mathrm{mg} / \mathrm{L}$ glutamine, $30 \mathrm{~g} / \mathrm{L}$ sucrose, and is solidified with $8 \mathrm{~g} / \mathrm{L}$ agar (Difco).

The embryonic axes were inoculated horizontally on agar culture medium at the rate of one embryonic axis $(6 \mathrm{~mm}$ in length on average) per flask. The flasks, containing 40 $\mathrm{mL}$ of the nutrient medium were covered with aluminum foil and closed with lids.

In this work, we also compared the reference medium with other media by culturing isolated zygotic embryos at different stages of development (young, intermediate and old). Thus, Woody Plant Medium (WPM) (McCown and Lloyd 1981), and MS macronutrients with MS micronutrients were tested. The other components of the media are those mentioned above. Among the auxins, only 2,4-D was used at different concentrations (from 2.26 to $9.05 \mu \mathrm{M}$ ) for each mineral solution. A combination of BAP $(4.4 \mu \mathrm{M})$ and 2,4-D $(4.52 \mu \mathrm{M})$ was also tested.

To these culture media, were added the following cofactors: ascorbic acid $(10.09 \mu \mathrm{M})$, nicotinic acid $(8.1 \mu \mathrm{M})$, glutamine $(2.73 \mathrm{mM})$, calcium pantothenate $(4.2 \mu \mathrm{M})$, pyridoxine hydrochloride $(4.9 \mu \mathrm{M})$ and thiamine $(3 \mu \mathrm{M})$.

Successive subcultures of the explants were carried out at one-month intervals on the same base medium, with no added growth regulators. The $\mathrm{pH}$ of the media was adjusted at 5.4-5.5 after the addition of all the compounds including growth regulators. Sterilization was carried out by autoclaving the media at $120^{\circ} \mathrm{C}$ for 20 minutes.

\section{Culture conditions}

The lighting conditions of the culture room were 16 hours of light and 8 hours of darkness per 24-hour cycle. The illumination of 4000 lux $\left(100 \mu \mathrm{M} \mathrm{m}^{-2} \mathrm{~s}-1\right)$ was provided by fluorescent tubes (Philips-40 W). The temperature was about $23 \pm 1^{\circ} \mathrm{C}$ during the day and $20 \pm 1^{\circ} \mathrm{C}$ at night.

Somatic embryogenesis from young leaves

Preparation of the explants

Limbs of apical leaves from 2-month-old seedlings, obtained through mature acorns germination, were excised into pieces of 1 to $1.5 \mathrm{~cm}$ with a scalpel.

\section{Leaves sterilization}

The leaves were superficially sterilized for 30 seconds in $70 \%$ alcohol, followed by 15 minutes bath in $10 \%(\mathrm{w} / \mathrm{v})$ calcium hypochlorite containing a few drops of Tween 80, and 1 minute in $0.1 \%(\mathrm{w} / \mathrm{v})$ solution of mercuric chloride. $\mathrm{HgCl}_{2}$ was then removed by 5 successive rinses of 5,5 , 10,10 and 15 minutes in sterile distilled water.

\section{Culture conditions}

After disinfection, the dorsal surface of leaves was deposited in contact with the solidified medium, in flasks containing about $20 \mathrm{~mL}$ of the medium covered with aluminum foil and closed with lids. A series of experiments were carried out: - For 8 days, the leaves are cultivated on the Gamborg (B5) macronutrients solution (Gamborg 1966) diluted in half without growth regulator and supplemented with 30 $\mathrm{g} / \mathrm{L}$ of sucrose. The cultures are placed in the dark and at $25^{\circ} \mathrm{C}$.

- Then the cultures were transferred to Schenk and Hildebrandt (SH) macronutrients (Schenk and Hildebrandt 
1972) or WPM, supplemented with $30 \mathrm{~g} / \mathrm{L}$ of sucrose, $10 \mu \mathrm{M}$ of NAA, and $10 \mu \mathrm{M}$ of BAP, under the same conditions as described previously.

- After 30 days, the leaves were transferred to light with a photoperiod of 16 hours at $25^{\circ} \mathrm{C}$, at a light intensity of about 4000 lux $\left(100 \mu \mathrm{M} \mathrm{m}^{-2} \mathrm{~s}^{-1}\right)$. The culture medium used consisted essentially of SH or WPM macronutrients to which $30 \mathrm{~g} / \mathrm{L}$ of sucrose and reduced concentrations of NAA $(0.5 \mu \mathrm{M})$ and BAP $(0.5 \mu \mathrm{M})$ were added.

- After one month, cultures were transferred to the same medium with no added growth regulators and were placed under the same conditions as above. The results were evaluated after 32 days.

All the experimented media were supplemented with MS micronutrients and vitamins, myo-inositol (100 mg/L), and solidified with $0.6 \mathrm{~g} / \mathrm{L}$ of agar. The $\mathrm{pH}$ is adjusted at 5.4-5.6.

\section{Statistical analysis}

A completely randomized experimental design was adopted. For each condition, 40 explants were used. The explants with somatic embryos are counted. Each experiment was repeated three times. The results of different experiments were evaluated by the analysis of variance (ANOVA) and the significantly different means were separated by Tukey post-hoc test $(p \leq 0.05)$.

\section{Results}

From immature zygotic embryos

Before culturing embryonic axes, we measured the different characteristics of 20 immature acorns of the cork oak, taken randomly from the AIN RAMI Seed Conservation Center. The results obtained were summarized in Table 1.

The cultured embryos provide a response depending on their degree of maturation. The young, still translucent ones, react in 89.3 to $96.2 \%$ of cases by the production of compact and friable calli that appeared from the second subculture on the growth regulators free medium, all over the surface of explants and more intensely in the hypocotyl. However, not all embryos were able to develop their roots. After the third transfer, 3.8 to $10.7 \%$ of the explants turned brown and showed a necrosis (Table 2).

Elderly zygotic embryos (Table 3), which have acquired a milky appearance, showing a presence of starch, led after culture, in the presence of BAP, to $86 \sim 95 \%$ of germi-
Table 1 Morphological characteristics of cork oak immature acorns

\begin{tabular}{lcc}
\hline & Mean value & CV (\%) \\
\hline Acorn fresh weight (mg) & $40.1 \pm 5.5$ & 14 \\
Acorn length (mm) & $31.1 \pm 1.8$ & 6 \\
Acorn maximum width (mm) & $13.7 \pm 0.9$ & 7 \\
Cup fresh weight (mg) & $8.3 \pm 2.1$ & 26 \\
Cup dry weight (mg) & $4.2 \pm 0.7$ & 18 \\
Albumen fresh weight (mg) & $11.9 \pm 1.9$ & 16 \\
Embryonic axis fresh weight (mg) & $0.14 \pm 0.03$ & 22 \\
Embryonic axis dry weight (mg) & $0.03 \pm 0.01$ & 29 \\
Embryonic axis length (mm) & $6.2 \pm 0.6$ & 10 \\
Embryonic axis width (mm) & $2.5 \pm 0.4$ & 17 \\
\hline
\end{tabular}

The data represent Mean $\pm \mathrm{SE}$ of replicates $(\mathrm{n}=3)$; CV: coefficient of variation.

nation. A small proportion $(5 \sim 14 \%)$ produced cellular proliferations essentially localized in the root tip. The calli were very undeveloped, brown and friable.

In the absence of cytokinin, 31.8 to $51.3 \%$ of the explants formed compact, friable and moderately developed calli, mainly at the periphery of the root tip. Small percentages (10.4 to $21.9 \%$ ) of embryos developed short and slender roots. The other explants remained quiescent and became necrotic after the second transfer to the growth regulators free medium of growth substances.

Taken from an intermediate stage, the embryos behave differently depending on the mineral solution used (Table 4). In Sommer and WPM macronutrients and in the presence of 2,4-D solely, 70.9 to $78.4 \%$ of the explants produced, at the end of the third subculture, brown, soft and less developed calli that were located mainly at the hypocotyl and sometimes at the root axis. The remaining explants have developed slender roots and some cellular proliferations at the hypocotyl.

These same observations were recorded for MS macronutrients in the presence of high concentrations of 2,4-D (6.78 and $9.05 \mu \mathrm{M})$. In the presence of $4.52 \mu \mathrm{M} 2,4-\mathrm{D}$, $20 \%$ of the explants gave rise to somatic embryos, after the third transfer to MS macronutriments with no added growth regulators. Somatic embryos were essentially located at the periphery of the root apex, which appeared to retain the longest morphogenic ability (Fig. 1).

Decreasing the concentration of 2,4-D led to a reduction of the percentage of explants forming somatic embryos at the end of the third subculture $(10 \%$ at $3.16 \mu \mathrm{M}$ and only $5 \%$ at $2.26 \mu \mathrm{M}$ ). The yellow somatic embryos were characterized essentially by two voluminous cotyledons and roots attached to the explants that have had spawned them. 
Table 2 Behavior of immature zygotic embryos taken at the young stage after one month of culture on three media (WPM, Sommer, and MS) with different concentrations of 2,4-D and BAP, and three subcultures for one month each on the same medium with no added growth regulators

\begin{tabular}{|c|c|c|c|c|c|c|c|}
\hline Medium & $\begin{array}{l}2,4-\mathrm{D} \\
(\mu \mathrm{M})\end{array}$ & $\begin{array}{l}\text { BAP } \\
(\mu \mathrm{M})\end{array}$ & $\begin{array}{c}\% \text { of } \\
\text { mortality }\end{array}$ & $\begin{array}{c}\% \text { of } \\
\text { non-morphogenic calli }\end{array}$ & $\begin{array}{l}\% \text { of } \\
\text { rooting }\end{array}$ & $\begin{array}{l}\% \text { of somatic } \\
\text { embryogenesis }\end{array}$ & $\begin{array}{c}\% \text { of } \\
\text { germination }\end{array}$ \\
\hline \multirow{7}{*}{ WPM } & 0.00 & 0.0 & $100.0^{b}$ & $0.0^{\mathrm{a}}$ & 0 & 0 & 0 \\
\hline & 2.26 & 0.0 & $5.7^{\mathrm{a}}$ & $94.3^{b}$ & 0 & 0 & 0 \\
\hline & 3.16 & 0.0 & $4.9^{\mathrm{a}}$ & $95.1^{\mathrm{b}}$ & 0 & 0 & 0 \\
\hline & 4.52 & 0.0 & $4.7^{\mathrm{a}}$ & $95.3^{\mathrm{b}}$ & 0 & 0 & 0 \\
\hline & 6.78 & 0.0 & $6.5^{\mathrm{a}}$ & $93.5^{\mathrm{b}}$ & 0 & 0 & 0 \\
\hline & 9.05 & 0.0 & $7.3^{\mathrm{a}}$ & $92.7^{\mathrm{b}}$ & 0 & 0 & 0 \\
\hline & 4.52 & 4.4 & $8.1^{\mathrm{a}}$ & $91.9^{\mathrm{b}}$ & 0 & 0 & 0 \\
\hline \multirow{7}{*}{ Sommer } & 0.00 & 0.0 & $100.0^{\mathrm{b}}$ & $0.0^{\mathrm{a}}$ & 0 & 0 & 0 \\
\hline & 2.26 & 0.0 & $6.7^{\mathrm{a}}$ & $93.3^{b}$ & 0 & 0 & 0 \\
\hline & 3.16 & 0.0 & $5.2^{\mathrm{a}}$ & $94.8^{\mathrm{b}}$ & 0 & 0 & 0 \\
\hline & 4.52 & 0.0 & $4.8^{\mathrm{a}}$ & $95.2^{\mathrm{b}}$ & 0 & 0 & 0 \\
\hline & 6.78 & 0.0 & $7.4^{\mathrm{a}}$ & $92.6^{\mathrm{b}}$ & 0 & 0 & 0 \\
\hline & 9.05 & 0.0 & $9.1^{\mathrm{a}}$ & $90.9^{\mathrm{b}}$ & 0 & 0 & 0 \\
\hline & 4.52 & 4.4 & $9.6^{\mathrm{a}}$ & $90.4^{\mathrm{b}}$ & 0 & 0 & 0 \\
\hline \multirow{7}{*}{ MS } & 0.00 & 0.0 & $100.0^{\mathrm{b}}$ & $0.0^{\mathrm{a}}$ & 0 & 0 & 0 \\
\hline & 2.26 & 0.0 & $6.6^{\mathrm{a}}$ & $93.4^{\mathrm{b}}$ & 0 & 0 & 0 \\
\hline & 3.16 & 0.0 & $6.3^{\mathrm{a}}$ & $93.7^{\mathrm{b}}$ & 0 & 0 & 0 \\
\hline & 4.52 & 0.0 & $3.8^{\mathrm{a}}$ & $96.2^{\mathrm{b}}$ & 0 & 0 & 0 \\
\hline & 6.78 & 0.0 & $7.9^{\mathrm{a}}$ & $92.1^{\mathrm{b}}$ & 0 & 0 & 0 \\
\hline & 9.05 & 0.0 & $9.8^{\mathrm{a}}$ & $90.2^{\mathrm{b}}$ & 0 & 0 & 0 \\
\hline & 4.52 & 4.4 & $10.7^{\mathrm{a}}$ & $89.3^{\mathrm{b}}$ & 0 & 0 & 0 \\
\hline
\end{tabular}

The data represent Mean of replicates $(n=3)$. Values in the same rows carrying different letters are significantly different between treatments and compared by Tukey's post-hoc test at $\mathrm{p} \leq 0.05$.

Table 3 Behavior of immature zygotic embryos taken at the elderly stage after one month of culture on three media (WPM, Sommer, and MS) with different concentrations of 2,4-D and BAP, and three subcultures for one month each on the same medium with no added growth regulators

\begin{tabular}{|c|c|c|c|c|c|c|c|}
\hline Medium & $\begin{array}{l}2,4-\mathrm{D} \\
(\mu \mathrm{M})\end{array}$ & $\begin{array}{l}\text { BAP } \\
(\mu \mathrm{M})\end{array}$ & $\begin{array}{c}\% \text { of } \\
\text { mortality }\end{array}$ & $\begin{array}{c}\% \text { of } \\
\text { non-morphogenic calli }\end{array}$ & $\begin{array}{l}\% \text { of } \\
\text { rooting }\end{array}$ & $\begin{array}{l}\% \text { of somatic } \\
\text { embryogenesis }\end{array}$ & $\begin{array}{c}\% \text { of } \\
\text { germination }\end{array}$ \\
\hline \multirow{7}{*}{ WPM } & 0.00 & 0.0 & $100.0^{c}$ & $0.0^{\mathrm{a}}$ & $0.0^{\mathrm{a}}$ & 0 & 0 \\
\hline & 2.26 & 0.0 & $49.1^{\mathrm{b}}$ & $34.2^{\mathrm{b}}$ & $16.7^{\mathrm{b}}$ & 0 & 0 \\
\hline & 3.16 & 0.0 & $47.4^{\mathrm{b}}$ & $35.4^{\mathrm{b}}$ & $17.2^{\mathrm{b}}$ & 0 & 0 \\
\hline & 4.52 & 0.0 & $42.2^{\mathrm{b}}$ & $38.2^{\mathrm{b}}$ & $19.6^{\mathrm{b}}$ & 0 & 0 \\
\hline & 6.78 & 0.0 & $45.3^{\mathrm{b}}$ & $36.8^{\mathrm{b}}$ & $17.9^{\mathrm{b}}$ & 0 & 0 \\
\hline & 9.05 & 0.0 & $48.8^{\mathrm{b}}$ & $33.9^{\mathrm{b}}$ & $17.3^{\mathrm{b}}$ & 0 & 0 \\
\hline & 4.52 & 4.4 & $0.0^{\mathrm{a}}$ & $5.0^{\mathrm{a}}$ & $0.0^{\mathrm{a}}$ & 0 & 95 \\
\hline \multirow{7}{*}{ Sommer } & 0.00 & 0.0 & $100.0^{\mathrm{c}}$ & $0.0^{\mathrm{a}}$ & $0.0^{\mathrm{a}}$ & 0 & 0 \\
\hline & 2.26 & 0.0 & $47.3^{\mathrm{b}}$ & $32.1^{\mathrm{b}}$ & $20.6^{\mathrm{b}}$ & 0 & 0 \\
\hline & 3.16 & 0.0 & $45.9^{\mathrm{b}}$ & $33.6^{\mathrm{b}}$ & $20.5^{\mathrm{b}}$ & 0 & 0 \\
\hline & 4.52 & 0.0 & $42.7^{\mathrm{b}}$ & $35.4^{\mathrm{b}}$ & $21.9^{\mathrm{b}}$ & 0 & 0 \\
\hline & 6.78 & 0.0 & $46.6^{\mathrm{b}}$ & $32.2^{\mathrm{b}}$ & $21.2^{\mathrm{b}}$ & 0 & 0 \\
\hline & 9.05 & 0.0 & $47.1^{\mathrm{b}}$ & $31.8^{\mathrm{b}}$ & $21.1^{\mathrm{b}}$ & 0 & 0 \\
\hline & 4.52 & 4.4 & $0.0^{\mathrm{a}}$ & $14.0^{\mathrm{a}}$ & $0.0^{\mathrm{a}}$ & 0 & 86 \\
\hline \multirow{7}{*}{ MS } & 0.00 & 0.0 & $100.0^{\mathrm{c}}$ & $0.0^{\mathrm{a}}$ & $0.0^{\mathrm{a}}$ & 0 & 0 \\
\hline & 2.26 & 0.0 & $44.6^{\mathrm{b}}$ & $43.1^{\mathrm{b}}$ & $12.3^{\mathrm{ab}}$ & 0 & 0 \\
\hline & 3.16 & 0.0 & $43.9^{\mathrm{b}}$ & $45.3^{\mathrm{b}}$ & $10.8^{\mathrm{ab}}$ & 0 & 0 \\
\hline & 4.52 & 0.0 & $38.3^{\mathrm{b}}$ & $51.3^{\mathrm{b}}$ & $10.4^{\mathrm{ab}}$ & 0 & 0 \\
\hline & 6.78 & 0.0 & $44.7^{\mathrm{b}}$ & $44.5^{\mathrm{b}}$ & $10.8^{\mathrm{ab}}$ & 0 & 0 \\
\hline & 9.05 & 0.0 & $46.9^{\mathrm{b}}$ & $41.8^{\mathrm{b}}$ & $11.3^{\mathrm{ab}}$ & 0 & 0 \\
\hline & 4.52 & 4.4 & $0.0^{\mathrm{a}}$ & $10.0^{\mathrm{a}}$ & $0.0^{\mathrm{a}}$ & 0 & 90 \\
\hline
\end{tabular}

The data represent Mean of replicates $(n=3)$. Values in the same rows carrying different letters are significantly different between treatments and compared by Tukey's post-hoc test at $\mathrm{p} \leq 0.05$. 
Table 4 Behavior of immature zygotic embryos taken at the intermediate stage after one month of culture on three media (WPM, Sommer, and MS) with different concentrations of 2,4-D and BAP, and three subcultures for one month each on the same medium with no added growth regulators

\begin{tabular}{|c|c|c|c|c|c|c|c|}
\hline Medium & $\begin{array}{l}2,4-\mathrm{D} \\
(\mu \mathrm{M})\end{array}$ & $\begin{array}{l}\text { BAP } \\
(\mu \mathrm{M})\end{array}$ & $\begin{array}{c}\% \text { of } \\
\text { mortality }\end{array}$ & $\begin{array}{c}\% \text { of } \\
\text { non-morphogenic calli }\end{array}$ & $\begin{array}{l}\% \text { of } \\
\text { rooting }\end{array}$ & $\begin{array}{l}\% \text { of somatic } \\
\text { embryogenesis }\end{array}$ & $\begin{array}{c}\% \text { of } \\
\text { germination }\end{array}$ \\
\hline \multirow{7}{*}{ WPM } & 0.00 & 0.0 & 100 & $0.0^{\mathrm{a}}$ & $0.0^{\mathrm{a}}$ & 0 & 0 \\
\hline & 2.26 & 0.0 & 0 & $75.8^{\mathrm{c}}$ & $24.2^{\mathrm{b}}$ & 0 & 0 \\
\hline & 3.16 & 0.0 & 0 & $73.4^{\mathrm{c}}$ & $26.6^{\mathrm{b}}$ & 0 & 0 \\
\hline & 4.52 & 0.0 & 0 & $70.9^{c}$ & $29.1^{\mathrm{b}}$ & 0 & 0 \\
\hline & 6.78 & 0.0 & 0 & $76.2^{\mathrm{c}}$ & $23.8^{\mathrm{b}}$ & 0 & 0 \\
\hline & 9.05 & 0.0 & 0 & $75.4^{\mathrm{c}}$ & $24.6^{\mathrm{b}}$ & 0 & 0 \\
\hline & 4.52 & 4.4 & 0 & $37.3^{\mathrm{b}}$ & $62.7^{\mathrm{c}}$ & 0 & 0 \\
\hline \multirow{7}{*}{ Sommer } & 0.00 & 0.0 & 100 & $0.0^{\mathrm{a}}$ & $0.0^{\mathrm{a}}$ & 0 & 0 \\
\hline & 2.26 & 0.0 & 0 & $71.5^{\mathrm{c}}$ & $28.5^{\mathrm{b}}$ & 0 & 0 \\
\hline & 3.16 & 0.0 & 0 & $77.2^{\mathrm{c}}$ & $22.8^{\mathrm{b}}$ & 0 & 0 \\
\hline & 4.52 & 0.0 & 0 & $71.2^{\mathrm{c}}$ & $28.8^{\mathrm{b}}$ & 0 & 0 \\
\hline & 6.78 & 0.0 & 0 & $77.6^{\mathrm{c}}$ & $22.4^{\mathrm{b}}$ & 0 & 0 \\
\hline & 9.05 & 0.0 & 0 & $78.4^{\mathrm{c}}$ & $21.6^{b}$ & 0 & 0 \\
\hline & 4.52 & 4.4 & 0 & $45.7^{\mathrm{b}}$ & $54.3^{\mathrm{c}}$ & 0 & 0 \\
\hline \multirow{7}{*}{ MS } & 0.00 & 0.0 & 100 & $0.0^{\mathrm{a}}$ & $0.0^{\mathrm{a}}$ & 0 & 0 \\
\hline & 2.26 & 0.0 & 0 & $68.8^{c}$ & $26.2^{b}$ & 5 & 0 \\
\hline & 3.16 & 0.0 & 0 & $71.1^{\mathrm{c}}$ & $18.9^{\mathrm{b}}$ & 10 & 0 \\
\hline & 4.52 & 0.0 & 0 & $58.2^{\mathrm{b}}$ & $21.8^{\mathrm{b}}$ & 20 & 0 \\
\hline & 6.78 & 0.0 & 0 & $72.7^{\mathrm{c}}$ & $27.3^{b}$ & 0 & 0 \\
\hline & 9.05 & 0.0 & 0 & $75.4^{\mathrm{c}}$ & $24.6^{\mathrm{b}}$ & 0 & 0 \\
\hline & 4.52 & 4.4 & 0 & $45.7^{\mathrm{b}}$ & $54.3^{c}$ & 0 & 0 \\
\hline
\end{tabular}

The data represent Mean of replicates $(n=3)$. Values in the same rows carrying different letters are significantly different between treatments and compared by Tukey's post-hoc test at $\mathrm{p} \leq 0.05$.

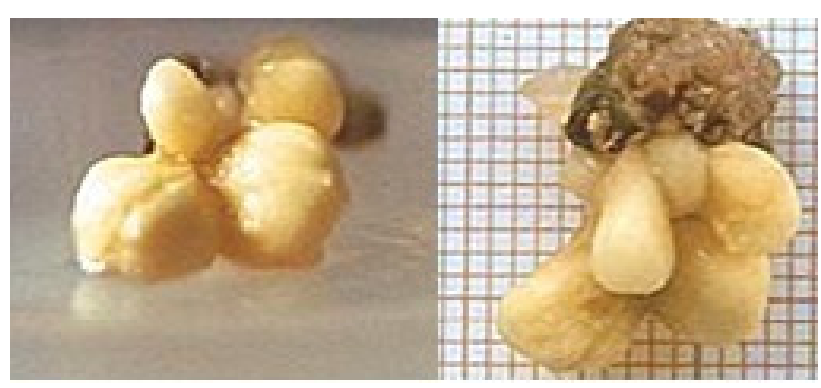

Fig. 1 Somatic embryos obtained from the culture of immature embryonic axes on MS medium supplemented with $4.52 \mu \mathrm{M}$ of 2,4-D followed by 3 subcultures on the same growth regulatorfree medium

After the fourth subculture, on the same medium, we observed that the embryos deviated from their normal path and began a process of vegetative multiplication. Thus, several secondary somatic embryos, translucent in appearance, appeared on the root of the primary somatic embryo. They continued their normal growth and acquired a yellowish color after only a few days. This process of multiplication is called secondary or recurrent embryogenesis, and is favored by a simple transfer to a growth regulators free medium. However, once the primary somatic embryos become green, the secondary embryogenesis ceases. We also noted that the somatic embryos turn green and become necrotic after few weeks. Thus, the mineral solution of MS was the most adapted and the concentration $4.52 \mu \mathrm{M}$ of 2,4-D was the most suitable to induce somatic embryogenesis from embryonic axes obtained from zygotic embryos at an intermediate stage of maturity.

From young leaves

Excised limbs of apical leaves from 2-month-old seedlings were used as explants for the induction of somatic embryogenesis (Fig. 2). They were cultured in the dark, on the dorsal side in contact with the agar medium, on one-half diluted B5 macronutrient solution, growth regulators free, to release phenolic compounds and to eliminate the contaminated explants.

After 8 days, the leaves were transferred to another agar medium (composed of SH or WPM macronutrients) supplemented with $10 \mu \mathrm{M}$ BAP and $10 \mu \mathrm{M}$ NAA, and were incubated in the dark.

After one month of culture, explants were transferred to light on the same culture medium, with $0.5 \mu \mathrm{M}$ BAP and $0.5 \mu \mathrm{M}$ NAA. After 30 days, the leaves were transferred to the same medium with no added growth regulators, in 


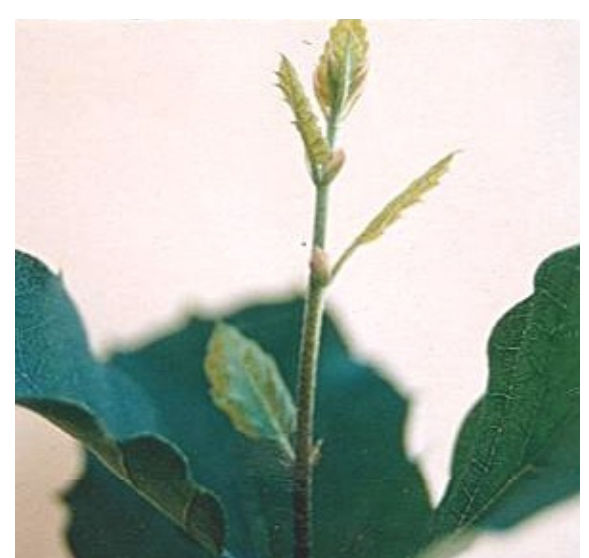

Fig. 2 Apical leaves taken from young seedlings ( 2 months) of cork oak grown on peat to be used for the induction of somatic embryogenesis

the light. The results were recorded 100 days after the initiation of the culture as reported in Table 5.

Our results showed that $16.8 \%$ of the leaves developed translucent somatic embryos on SH macronutrients solution. Their average length was about $3 \mathrm{~mm}$. After the second week of culture, the embryos became opaque, yellow and their length reached an average of $10.2 \mathrm{~mm}$. The average number of somatic embryos per leaf was about 2.8. These somatic embryos were located at the base of leaves and were characterized by their two voluminous cotyledons and their roots attached to the leaves that spawned them. A few leaves (12.2\%) turned brown and necrotic one week after their transfer to the medium without growth regulators. The other explants (71\%) remained quiescent even after a second subculture on $\mathrm{SH}$ growth regulators free medium.

We also observed a relatively higher percentage of the somatic embryos (23.3\%) on WPM macronutrients solution (Fig. 3).

Somatic embryogenesis occurred earlier. Thus, $10 \%$ of the leaves presented somatic embryogenesis before their transfer to the growth regulators free medium or after three weeks of culture on WPM macronutrients solution supplemented with $0.5 \mu \mathrm{M}$ of BAP and $0.5 \mu \mathrm{M}$ of NAA. The

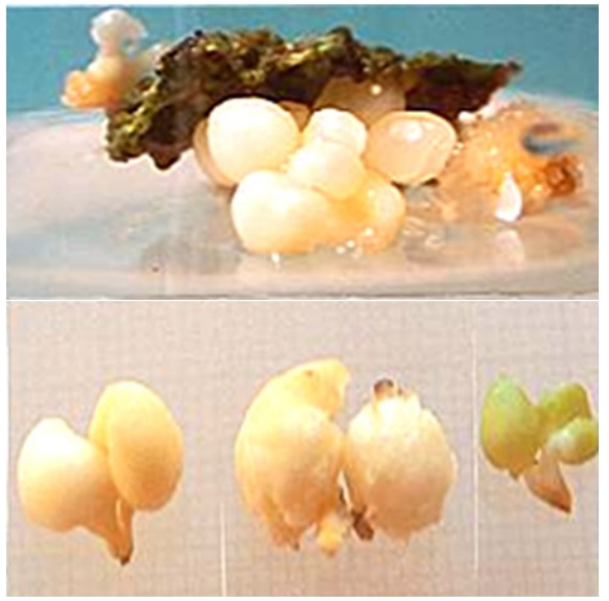

Fig. 3 Somatic embryos obtained from the culture of apical leaves after 8 days in the dark on mineral solution of B5 diluted to half, 30 days in the dark, followed by 30 days in the light on WPM containing NAA and BAP

average number of somatic embryos per leaf was about 4.8. The embryos were established at the base of the leaves and sometimes at the surface of the leaves, so out of the medium. They are initially translucent, with an average length of $4 \mathrm{~mm}$, and then they continue growing to become opaque and yellow and reach $12.2 \mathrm{~mm}$. These embryos were characterized by their two cotyledons, which are larger than those obtained on SH macronutrients solution and were always attached by their roots to the leaves that produced them. A small percentage of the leaves (13.4\%) showed necrosis and died two weeks after transplanting to the growth regulators free medium.

We also observed a callus proliferation that covered all the leaves in $34.2 \%$ of the cases. These calli were generally translucent, friable and they became brown a few weeks after their formation. $14 \%$ of the leaves form, in addition to callus proliferation, a slender root with an average length of $2.1 \mathrm{~cm}$. However, a small percentage of leaves (15.1\%) did not react to the somatic embryogenesis, even after several subcultures on growth regulators free medium.

Our results showed that the WPM macronutrients so-

Table 5 Effect of SH and WPM media on the somatic embryogenesis of young cork oak leaves, cultured 8 days in the dark on the solution B5 diluted in half, 30 days in the dark, followed by 30 days in the light in the presence of growth regulators, and finally 32 days in the light without growth regulators

\begin{tabular}{cccccccc}
\hline Medium & $\begin{array}{c}\% \text { of } \\
\text { explants without } \\
\text { reaction }\end{array}$ & $\begin{array}{c}\% \text { of } \\
\text { mortality }\end{array}$ & $\begin{array}{c}\text { \% of somatic } \\
\text { embryogenesis }\end{array}$ & $\begin{array}{c}\text { Mean number } \\
\text { of somatic } \\
\text { embryos per leaf }\end{array}$ & $\begin{array}{c}\text { Mean length } \\
\text { of somatic } \\
\text { embryos (mm) }\end{array}$ & $\begin{array}{c}\% \text { of explant } \\
\text { with callus }\end{array}$ & $\begin{array}{c}\% \text { of explants } \\
\text { with callus } \\
\text { and root }\end{array}$ \\
\hline SH & $71^{\mathrm{b}}$ & $12.2^{\mathrm{a}}$ & $16.8^{\mathrm{a}}$ & $2.8 \pm 0.1^{\mathrm{a}}$ & $10.2 \pm 0.1^{\mathrm{a}}$ & $0^{\mathrm{a}}$ & $0^{\mathrm{a}}$ \\
WPM & $15.1^{\mathrm{a}}$ & $13.4^{\mathrm{a}}$ & $23.3^{\mathrm{b}}$ & $4.8 \pm 0.1^{\mathrm{b}}$ & $12.2 \pm 0.1^{\mathrm{b}}$ & $34.2^{\mathrm{b}}$ & $14.0^{\mathrm{b}}$ \\
\hline
\end{tabular}

The data represent Mean \pm SE of replicates $(n=3)$. Values in the same rows carrying different letters are significantly different between treatments and compared by Tukey's post-hoc test at $\mathrm{p} \leq 0.05$. 


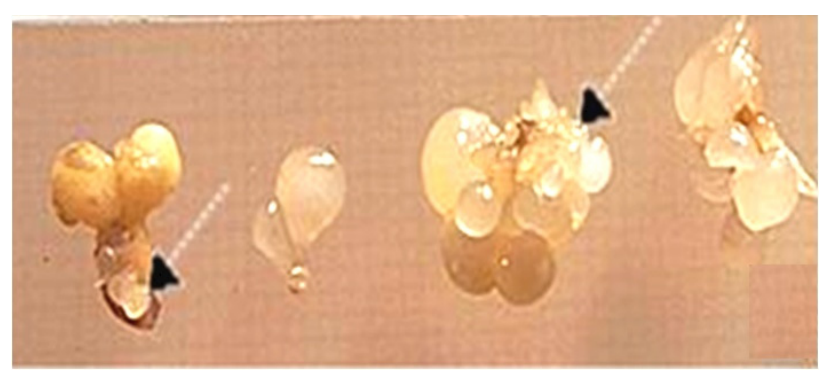

Fig. 4 Secondary somatic embryos obtained by transferring the primary somatic embryos to the growth regulator-free induction medium containing WPM macronutrients, MS microelements, and vitamins. They were established mainly on the radicle of the primary somatic embryo (arrow)

lution was the most suitable for somatic embryogenesis induction from apical leaves of young cork oak seedlings.

The maintenance of somatic embryogenesis is ensured by secondary embryogenesis. This latter was achieved by simple transplanting of the somatic embryos, for one month, on a medium without growth regulators under light conditions.

Secondary somatic embryos were developed primarily on the root of the primary somatic embryo (Fig. 4). This process of secondary somatic embryogenesis ceased when somatic embryos became older, ripened and took a green appearance.

\section{Discussion}

The induction of somatic embryogenesis of forest species has been intensively investigated (Dunstan et al., 1995; Thorpe et al., 1991). In these researches, somatic embryogenesis was generally started from immature zygotic embryos using different mineral compositions and various combinations and concentrations of growth regulators.

In the case of the genus Quercus, the medium used most frequently is that of MS. Somatic embryogenesis was obtained using other media such as WPM (Chalupa 1990; Gingas and Lineberger 1989) and Sommer (Pintos et al. 2008), starting from zygotic embryos.

Our results showed that among the tested macronutrients solutions (Sommer, MS and WPM), the MS macronutrients is the most suitable for somatic embryogenesis induction from zygotic embryos of intermediate maturity in cork oak. These findings corroborated with those reported in the literature (El Maataoui and Espagnac 1987; El Maataoui et al. 1990; Feraud-Keller et al. 1989; Hernandez et al. 2003a; Pinto et al. 2002). However, somatic embryogenesis from zygotic embryos was also obtained using other media such as WPM (Chalupa 1990; Gingas and Lineberger 1989) and
Sommer (Bueno et al. 1992; Gallego et al. 1997; Manzanera et al. 1993; Pintos et al. 2008).

The cork oak zygotic embryos developed calli under the influence of 2,4-D. These calli were mainly located on the hypocotyl. These results reminded those obtained by Bueno et al. (1992) and Manzanera et al. (1993) using the same species.

Growth regulators play an important role in the induction and stimulation of the somatic embryogenesis process. Some authors give priority to auxins (Dameri et al. 1986; Pintos et al. 2008; Reynolds and Murashige 1979), while others are in favor of cytokinins, especially BAP (Pretova and Williams 1986 a, b; Williams and Maheswaran 1986). Generally, the process of somatic embryogenesis is stimulated by various concentrations and combinations of growth substances (Ostrolucka and Pretova 1991).

Our results indicated that 2,4-D was the most efficient growth regulator in somatic embryogenesis induction, compared with the combinations of BAP and NAA. Manzanera (1992) reported the same findings in Quercus robur, and Pintos et al. (2008) in Quercus suber, Other authors observed the important role of 2,4-D in cell division and embryogenic potential (Lelu and Bornman 1990; Steward et al. 1964; Sung et al. 1988). In contrast, Chalupa (1990) obtained somatic embryogenesis from Quercus robur embryos using BAP solely or in combination with $\mathrm{GA}_{3}$. 2,4-D was found to be ineffective. Furthermore, 2,4-D was pointed out as an inhibitor of embryos development (Halperin 1970). As well, Kim et al. (1994; 1997) obtained induction of somatic embryogenesis from immature zygotic embryos of Quercus acutissima, on MS medium supplemented with only IBA or in combination with $4.4 \mu \mathrm{M}$ of BAP. They have also shown that the addition of BAP is generally beneficial for the induction of embryogenic cultures from immature zygotic embryos.

Induction of somatic embryogenesis was generally performed at low frequency, and exclusively under photoperiod conditions as indicated in Quercus rubra (Gingas and Lineberger 1989).

Chalupa (1990) used immature zygotic embryos of Quercus robur in the dark and obtained white embryogenic tissues after 5 to 7 weeks of culture. Thus, the somatic embryogenesis induction in darkness did not produce good results.

Our findings suggest that somatic embryogenesis occurs directly (without undergoing the callus stage), probably because immature zygotic embryos are entirely composed of meristematic cells (El Maataoui et al. 1990). Indeed, the histological study carried out by El Maataoui and Espagnac (1989) showed that the somatic embryos of cork oak grow 
directly without prior callus production. As for the other examples of direct somatic embryogenesis (Lu and Vasil 1985; Michaux-Ferriere et al. 1992; Quinn et al. 1989; Taylor and Vasil 1996; Wang et al. 1994; Williams and Maheswaran 1986), they seemed to come either from superficial multicellular clusters or from epidermal cells that have become embryogenic.

After transfer on media containing BAP and NAA of leaves obtained from seedlings of germination as described by Fernandez-Guijarro et al. (1995) and leaves obtained from mature tree cuttings as described by Toribio et al. (2000). Our results proved that the WPM macronutrients solution is more adapted to the somatic embryogenesis of young cork oak leaves than SH macronutrients solution. Indeed, the macronutrients solution WPM was reported to induce somatic embryogenesis in young leaves of Quercus rubra grown in the presence of 2,4-D and BAP (Rancillac et al. 1994). Thus, the combination of NAA and BAP was used for the initiation of somatic embryogenesis from Quercus robur young leaves (Cuenca et al. 1999). However, Fernandez-Guijarro et al. (1995) reported that SH macronutrients solution induced somatic embryogenesis in Quercus suber sprouting leaves, but with a low frequency (5\%). Besides, Hernandez et al. (2003a) signaled that a higher frequency (26\%) of somatic embryogenesis induction from leaves of mature tree cuttings was obtained on this medium.

We placed the dorsal surface of the leaves in contact with the agar medium. Indeed, Rancillac et al. (1996) showed that the somatic embryogenesis of the young leaves discs of Quercus rubra is obtained only in light and when the dorsal surface of the leaves is in contact with the medium. It is possible to obtain a high number of somatic embryos on a single explant (Chalupa 1990; Gingas and Lineberger 1989; Manzanera et al. 1993; Ostrolucka and Krajmerova 1996). However, in our case, the frequency of induced somatic embryos was relatively low, since we obtained about five somatic embryos per leave on WPM medium. This result is similar to that obtained in Quercus ilex leaves (FeraudKeller and Espagnac 1989) and Quercus suber internodes and leaves (El Maataoui and Espagnac 1987; FernandezGuijarro et al. 1995; Hernandez et al. 2003a).

This situation could be compensated by the initiation of secondary somatic embryogenesis. This behavior must certainly be compared with that of somatic embryos obtained on calli from caulinary origin (El Maataoui and Espagnac 1987).

Secondary embryogenesis occured in cork oak on a media free of growth regulators (El Maataoui et al. 1990; FernandezGuijarro et al. 1993; Fernandez-Guijarro et al. 1995; Hernandez et al. 2003a, b; Puigderrajols et al. 1996; 2000) and took place at the radicular pole of embryos isolated in subculture (Rancillac et al. 1993).

Similarly, secondary embryogenesis of Quercus acutissima was ensured by a simple transplanting to MS medium free of growth regulators (Halperin 1970). It could also be carried out in sessile oak (Quercus robur) by transfer to a medium containing a low concentration of BAP (Chalupa 1995; Cuenca et al. 1999; Endemann and Withelm 1997; Ostrolucka and Krajmerova 1996).

\section{Conclusion}

The considerable development of research in somatic embryogenesis has aroused a renewed interest in immature zygotic embryos. In this field, they are not only used to initiate embryogenic processes in many species but also to address the nutritional and behavioral aspects of which knowledge is needed before any introduction of somatic embryos into plant breeding programs. In this work, we have developed techniques for obtaining somatic embryos from both immature zygotic embryos excised at different stages of growth and apical leaves taken from young seedlings of oak cork.

Thus, we recorded a very important callogenesis (100\%) on immature zygotic embryos. The calli were compact and friable and developed over the entire surface of the embryonic axis, mainly on the hypocotyl.

Similarly, we induced callogenesis from young apical leaves with a non-negligible percentage of calli (34.2\%). They covered all the leaves on the WPM medium, were generally translucent, friable and turned brown a few weeks after their formation. Moreover, it appears that the stage of development and therefore, the physiological state at the time of excision play a considerable role in their behavior.

Our results indicated that MS macronutrients solution was the most suitable to somatic embryogenesis induction from intermediate maturing zygotic embryos and the concentration of $4.52 \mu \mathrm{M}$ of $2,4-\mathrm{D}$ was the most adapted $(20 \%$ of embryonic axes formed somatic embryos).

As well, we demonstrated that WPM medium was more favorable than SH medium for inducing somatic embryogenesis from the apical leaves of young cork oak seedlings.

The frequency of obtaining somatic embryos was generally low. This issue was compensated by establishing secondary somatic embryogenesis, which resulted in continuous and unlimited embryogenesis. In cork oak, recurrent somatic embryogenesis was frequent and led to the formation of a high number of secondary embryos. Interestingly, we noticed that once induced, the somatic embryogenesis process continues by itself giving recurrent embryogenesis. However, 
to obtain proper germination of somatic embryos, secondary embryogenesis must be stopped.

Therefore, the multiplication of somatic embryos and conversion into seedlings can be considered as results of the same process. Indeed, depending on the treatment applied, it is possible to increase the multiplicative capacities of explants or to enhance the production of the seedlings.

\section{References}

Bonga JM (1991) In vitro propagation of Conifers: Fidelity of the clonal offspring. In: Woody plant biotechnology (Ahuja MR eds), p.13-21. Plenum Press, New York

Bueno MA, Astorga R, Manzanera JA (1992) Plant regeneration through somatic embryogenesis in Quercus suber. Physiol Plant 85(1):30-34

Bueno MA, Manzanera JA (1992) Primeros ensayos de inducción de embrioides somáticos de Quercus suber L. Scientia Gerundensis 18:29-37

Chalupa V (1990) Plant regeneration by somatic embryogenesis from cultured immature embryos of Oak (Quercus robur $\mathrm{L}$ ) and Linden (Tilia cordata Mill). Plant Cell Rep 9(7):398-401

Chalupa V (1995) Somatic embryogenesis in Oak (Quercus spp). In: Embryogenesis in woody plants, (Jain S, Gupta P, Newton R eds) 2:67-87

Cuenca B, San-Jose MC, Martinez MT, Ballester A, Vieitez AM (1999) Somatic embryogenesis from stem and leaf explants of Quercus robur L. Plant cell Rep 18:538-543

Dameri RM, Caffaro L, Gastaldo P, Profumo P (1986) Callus formation and embryogenesis from leaf explants of Aesculus hippocastanum L. J Plant Physiol 126:93-96

Dunstan DI, Tautorus TE, Thorpe TA (1995) Somatic embryogenesis in woody plants. In: In vitro embryogenesis in plants (Thorpe TA eds), p. 471-538. Kluwer Academic, Dordrecht

El Maataoui M, Espagnac H (1987) Néoformation de structures de type embryons somatiques sur des cultures de tissus de Chêne-liège (Quercus suber L). C R Acad Sci Ser III 304(3): 83-88

El Maataoui M, Espagnac H (1989) Comportement in vitro d'embryons zygotiques de Chêne-liège (Quercus suber L) excisés à divers stades de leur développement. Ann Sci For 46 suppl: $145 \mathrm{~s}-148 \mathrm{~s}$

El Maataoui M, Espagnac H, Michaux-Ferriere N (1990) Histology of callogenesis and somatic embryogenesis induced in stem fragments of Cork Oak (Quercus suber) cultured in vitro. Ann Bot (London) 66:183-190

Endemann M, Withelm E(1997) Induction of somatic embryogenesis in Quercus robur. Abst COST 822, working group 3: Identification and control of phase changes in rejuvenation. Nitra. Slovak Republic, p. 42-44

Feraud-Keller C, Espagnac H (1989) Conditions d'apparition d'une embryogénèse somatique sur des cals issus de la culture de tissus foliaires du Chêne Vert (Quercus ilex). Can J Bot 67: 1066-1070
Feraud-Keller C, El Maataoui M, Gouin O, Espagnac H (1989) Embryogenèse somatique chez trois espèces de Chênes Méditerranéens. Ann Sci For 46 suppl: 130s-132s

Fernandez-Guijarro B, Celestino C, Toribio M (1993) Somatic embryogenesis in Quercus suber L. In: Biotechnology of trees, (Pardos JA, Ahuja MR, Rossello R eds), 18-22 October, 1993 Valsain - Spain, p. 105-110

Fernandez-Guijarro B, Celestino C, Toribio M (1995) Influence of external factors on secondary embryogenesis and germination in somatic embryos from leaves of Quercus suber. Plant Cell Tissue Organ Cult 41:99-106

Gallego FJ, Martinez I, Celestino C., Toribio M (1997) Testing somaclonal variation using RAPDs in Quercus suber L somatic embryos. Int J Plant Sci 158(5):563-567

Gamborg OL (1966) Aromatic metabolism in plants. II. Enzymes of the shikimate pathway in suspension cultures of plant cells. Canadian Journal of Biochemistry 44:791-799

Gingas VM, Lineberger RD (1989) Asexual embryogenesis and plant regeneration in Quercus. Plant Cell Tissue Organ Cult 17: 191-203

Gomez-Garay A, Manzanera JA, Pintos B (2014) Embryogenesis in Oak species. A review. Forest Systems 23(2):191-198

Halperin W (1970) Embryos from somatic plant cells. Proc Intl Soc Cell Biol Symp 9:169-191

Hernandez I, Celestino C, Toribio M(2003a) Vegetative propagation of Quercus suber L by somatic embryogenesis. I. Factors affecting the induction in leaves from mature Cork Oak trees. Plant Cell Rep 21:759-764

Hernandez I, Celestino C, Alegre J, Toribio M (2003b) Vegetative propagation of Quercus suber L by somatic embryogenesis. II. Plant regeneration from selected Cork Oak trees. Plant Cell Rep 21:765-770

Kim YW, Lee BC, Lee SK, Jang SS (1994) Somatic embryogenesis and plant regeneration in Quercus acutissima. Plant Cell Rep 13:315-318

Kim YW, Youn Y, Noh ER, Kim JC (1997) Somatic embryogenesis and plant regeneration from immature embryos of five families of Quercus acutissima. Plant Cell Rep 16:869-873

Lelu MAP, Bornman CH (1990) Induction of somatic embryogenesis in excised cotyledons of Picea glauca and Picea mariana. Plant Physiol Biochem 28:785-791

Lu C, Vasil IK (1985) Histology of somatic embryogenesis in Panicum maximum (Guinea grass). Am J Bot 72:1908-1913

Manzanera JA (1992) Inducción de embriogénesis somática en Roble (Quercus robur L). Investigación Agraria, Serie Sistemas y Recursos Forestales 1(1):73-81

Manzanera JA, Astorga R, Bueno MA (1993) Somatic embryo induction and germination in Quercus suber L. Silvae Genet 42(2-3):90-93

McCown BH, Lloyd G (1981) Woody plant medium (WPM) - A mineral nutrient formulation for microculture of woody plant species. HortScience 16(3):453

Merkle SA (1995) Strategies for dealing with limitations of somatic embryogenesis in hardwood trees. Plant Tissue Cult Biotech 1: 112-121 
Michaux-Ferriere N, Grout H, Carron MP (1992) Origin and ontogenesis of somatic embryos in Hevea brasiliensis (Euphorbiaceae). Am J Bot 79: 174-180

Murashige T, Skoog F (1962) A revised medium for rapid growth and bioassays with Tobacco tissue culture. Physiol Plant 15: 473-497

Ostrolucka MG, Krajmerova D (1996) Manifestation of embryogenic potential in culture of zygotic embryos of Quercus robur L. Acta Soc Bot Pol 65(1-2):37-41

Ostrolucka MG, Pretova A (1991) The occurrence of somatic embryogenesis in the species Quercus cerris L. Biologia (Bratislava) 46(1):9-14

Pinto G, Park Y-S, Silva S, Araújo C, Neves L, Santos C (2008) Factors affecting maintenance, proliferation, and germination of secondary somatic embryos of Eucalyptus globulus Labill. Plant Cell Tiss Organ Cult 95:69-78

Pinto G, Valentim H, Costa A, Castro S, Santos C (2002) Somatic embryogenesis in leaf plant calluses of mature Quercus suber. In Vitro Cell Div Biol - Plant 38:569-572

Pintos B, Bueno MA, Cuenca B, Manzanera JA (2008) Synthetic seed production from encapsulated somatic embryos of Cork Oak (Quercus suber L) and automated growth monitoring. Plant Cell Tiss Organ Cult 95:217-225

Pretova A, Williams EG(1986a) Direct somatic embryogenesis from immature zygotic embryos of Flax (Linum usitatissimum L). Plant Physiol 126(2-3):155-161

Pretova A, Williams EG(1986b) Zygotic embryo cloning in oil seed Rape (Brassica napus L). Plant Science 47(3):195-197

Puigderrajols P, Celestino C, Suils M, Toribio M, Molinas M(2000) Histology of organogenic and embryogenic responses in cotyledons of somatic embryos of Quercus suber L. Int J Plant Sci 161(3):353-362

Puigderrajols P, Fernandez-Guijarro B, Toribio M, Molinas ML (1996) Origin and early development of secondary embryos in Quercus suber L. Int J Plant Sci 157(6):674-684

Quinn J, Simon JE, Janick J (1989) Histology of zygotic and somatic embryogenesis in Borage. Journal American Society of Horticultural Science 114:516-520

Rancillac M, El-Hamri I, Klinguer A (1994) Expression of somatic embryogenesis from leaf discs in a forest tree, the American Red Oak. Plant Sci p. 78
Rancillac M, Klinguer A, Klinguer S (1993) Biotechnologies appliquées à un arbre forestier, le Chêne Rouge Américain (Quercus rubra L). Acta Bot Gallica 140(6):722

Rancillac M, Klinguer A, Klinguer S, Millet B (1996) Preliminary investigations on somatic embryogenesis from leaf discs of Red Oak (Quercus rubra L). Plant Growth Regul 20(1):67-73

Reynolds JF, Murashige T (1979) Asexual embryogenesis in callus cultures of Palms. In Vitro 5:383-387

Schenk RV, Hildebrandt AC (1972) Medium and techniques for induction and growth of monocotyledonous and dicotyledonous plant cell cultures. Can J Bot 50:199-204

Sommer HF (1975) Differentiation of adventitious buds on Douglas fir embryos in vitro. Proc Int Plant Propagators Soc 25:125-127

Steward FC, Mapes MO, Kent AE, Holsten RD (1964) Growth and development of cultured plant cells. Science 143:20-27

Sung ZR, Smith JM, Choi JH, Krauss M, Borkird C, Liu LS (1988) Gene expression in embryogenesis. HortScience 23:513-515

Taylor MG, Vasil IK (1996) The ultrastructure of somatic embryo development in pearl millet (Pennsisetum glaucum, Poaceae). Am J Bot 83:28-44

Thorpe TA, Harry IS, Kumar PP (1991) Application of micropropagation to forestry. In: Micropropagation, technology and application (Debergh PC, Zimmerman RH eds), p. 311-336. Kluwer Academic, Dordrecht

Toribio M, Celestino C (1989) Cultivo in vitro del alcornoque. Scientia gerundensis 15:11-21

Toribio M (1986) Callus initiation and primary morphogenic responses from Quercus suber L cotyledons cultured in vitro. $18^{\text {th }}$ Congress IUFRO, Division 2, 7-21 September

Toribio M, Celestino C, Gallego J, Martinez I (2000) Induction of somatic embryogenesis in tissues from mature oak trees. in: Riordain FO (eds) development of integrated systems for large-scale propagation of elite plants using in vitro techniques. EUR 19237 COST Action 822, Report of activities 1998. Office for Official Publications of the European Communities, Luxembourg, pp 236-237

Wang L, Bao X, Liu Y, Hao S (1994) Origin of direct somatic embryos from cultured inflorescence axis segments of Freesia refracta. Int J Plant Sci 155:672-676

Williams EG, Maheswaran G (1986) Somatic embryogenesis: factors influencing coordinated behaviour of cells as an embryogenic group. Annals of Botany 57(4):443-462 